\title{
IMPLEMENTASI METODE PROMETHEE DALAM MENENTUKAN CALON PENERIMA BANTUAN PKH BERBASIH WEB (STUDI KASUS: DESA TENGGULI KECAMATAN SAJAD)
}

\author{
${ }^{[1]}$ Mohani, ${ }^{[2]}$ Cucu Suhery, ${ }^{[3]}$ Uray Ristian \\ [1] [2] [3]Jurusan Rekayasa Sistem Komputer, Fakultas MIPA Universitas Tanjungpura \\ Jalan Prof Dr. H. Hadari Nawawi Pontianak \\ Telp./Fax. : (0561) 577963 \\ e-mail: ${ }^{[1]}$ mohanisiskom@untan.ac.id, ${ }^{[2]}$ csuhery@ siskom.untan.ac.id, \\ ${ }^{[3]}$ eristian@ siskom.untan.ac.id
}

\begin{abstract}
ABSTRAK
Saat ini, pengambilan data yang akan digunakan dalam pelaksanaan seleksi Program Keluarga Harapan (PKH) untuk pemberian bantuan kepada 20 keluarga kurang mampu di Desa Tengguli Kabupaten Sambas Kalimantan Barat, dilakukan oleh petugas dengan cara mendatangi rumah-rumah penduduk secara langsung. Data yang diambil oleh petugas antara lain jenis lantai, jenis dinding, dan jumlah orang. Namun dalam proses seleksinya hanya membandingkan data-data yang ada secara kasat mata tanpa menggunakan perhitungan yang sebagaimana mestinya, sehingga membutuhkan waktu yang cukup banyak dalam proses seleksinya. Penelitian ini bertujuan membangun sebuah sistem yang digunakan untuk menentukan calon-calon penerima bantuan PKH menggunakan metode Promethee. Keluaran yang dihasilkan berupa nilai Net Flow yang digunakan sebagai acuan dalam menentukan calon penerima bantuan berdasarkan urutan nilai Net Flow terbesar ke nilai terkecil. Dari hasil pengujian 200 kepala keluarga, diperoleh nilai Net Flow terbesar adalah 0,219221 dan nilai Net Flow terkecil adalah 0,362437 . Berdasarkan hal tersebut, maka yang mendapatkan bantuan PKH pada Desa Tengguli adalah 11 kepala keluarga dari Dusun Pelok, 3 kepala keluarga dari Dusun Pemidingan, 5 kepala keluarga dari Dusun Sawang, dan 1 kepala keluarga dari Dusun Sajat. Sedangkan pengujian sistem aplikasi dilakukan dengan menggunakan White Box, dan diperoleh hasil bahwa sistem sudah berfungsi sesuai dengan rancangan.
\end{abstract}

Kata kunci: PKH, Promethee, White Box, Net Flow, Rangking.

\section{PENDAHULUAN}

Program Keluarga Harapan $(\mathrm{PKH})$ menurut [1] adalah program pemberian bantuan sosial bersyarat kepada Keluarga Penerima Manfaat (KPM) yang ditetapkan sebagai keluarga penerima manfaat PKH. PKH merupakan program dari Pemerintah Indonesia dalam hal ini diwakili oleh Kementrian Sosial Republik Indonesia untuk membantu dan meringankan biaya hidup keluarga yang kurang mampu. Kriteria yang digunakan adalah penghasilan, jumlah tabungan, luas bangunan, jenis lantai, jenis dinding, biaya pengobatan, jumlah makan perhari, sembako, sumber penerangan, sumber air bersih, alat memasak, jumlah tanggungan, usia lanjut, jumlah anak sekolah. penyandang disabilitas, ibu hamil/menyusui. Program ini dilaksanakan di seluruh Indonesia melalui bantuan dari seluruh Kantor Desa yang ada di Indonesia. Salah satunya adalah Kantor Desa Tengguli.

Desa Tengguli merupakan salah satu Desa yang ada di Kecamatan Sajad Kabupaten Sambas Kalimantan Barat. Kecamatan Sajad terdapat 4 Desa, yaitu: Desa Tengguli, Jirak, Mekar Jaya dan Beringin. Berdasarkan data dari Kantor Desa Tengguli jumlah penduduk pada bulan Oktober 2019 berjumlah 5012 jiwa. Untuk memberikan bantuan kepada masyarakat yang membutuhkan bantuan sosial, pegawai kantor Desa Tengguli harus melakukan pengambilan data terlebih dahulu ke setiap rumah-rumah yang dianggap layak untuk menerima bantuan PKH.

Pengambilan data dalam pemberian bantuan PKH kepada keluarga kurang mampu 
saat ini, di Desa Tengguli dilakukan oleh petugas dengan cara mendatangi rumah-rumah secara langsung. Data yang diambil seperti: jenis lantai, jenis dinding, dan jumlah orang. Setelah data diambil kemudian dilakukan proses seleksi dengan membandingkan datadata yang telah dikumpulkan.

Penelitian tentang Sistem Pendukung Keputusan dilakukan oleh [2] dengan judul "Sistem Pendukung Keputusan untuk Menentukan Siswa Lulusan Terbaik Menggunakan Metode Promethee (Studi Kasus: SMA Negeri 3 Pontianak)". Penelitian tersebut menggunakan empat kriteria yaitu nilai rapor, nilai ujian nasional, nilai ujian sekolah dan prestasi tingkat kota, provinsi dan nasional atau internasional. Hasil perhitungan dari 26 siswa yang diranking mendapatkan 1 terbaik yaitu Hardo Triwahyu.

Penelitian lain menggunakan metode Promethee telah dilakukan oleh [3] dengan judul "Sistem Pendukung Keputusan Seleksi Calon Karyawan Dengan Metode Promethee Studi Kasus Pamella Group Yogyakarta". Penelitian tersebut menggunakan enam kriteria yaitu pegawaiistrasi, tes tertulis, psikologi, kesehatan, wawancara dan pengalaman. Hasil perhitungan dari 4 pelamar yang dirangking menggunakan Promethe yaitu Dui Oktavia, Piranda, Reny Retnowati, Tri Afriliyanti.

Selain itu penelitian yang menggunakan metode Promethee juga dilakukan oleh [4] dengan judul "Penerapan Metode Promethee dalam Penyeleksian Siswa Baru (Airlines Staff) pada Lembaga Pelatihan Penerbangan". Penelitian ini menggunakan lima kriteria yaitu umur, tinggi badan, kesehatan, penampilan dan bahasa inggris. Penelitian ini menggunakan metode promethee dengan merangking nilai tertinggi ke terendah serta rekomendasi diterima dan ditolak.

Kemudian penelitian tentang metode Promethee juga dilakukan oleh [5] dengan judul "Sistem Pendukung Keputusan Menggunakan Metode Promethee (Studi Kasus: Stasiun Pengisian Bahan Bakar Umum)". Penelitian ini menghasilkan sebuah sistem untuk merangking tempat-tempat yang cocok untuk dibangun sebuah SPBU di Yogyakarta dengan kriteria luas tanah, harga tanah, kepadatan lalu lintas, banyak jalur angkutan, jarak dengan SPBU lain. Hasil dari penelitian ini memberikan hasil keputusan yang objektif. Keputusan yang dihasilkan oleh sistem bukan merupakan hasil yang mutlak dimana keputusan akhir tetap ditentukan oleh user.

Berdasarkan permasalahan dalam proses pengambilan dan seleksi data, maka dilakukan penelitian dengan judul "Implementasi Metode Promethee Dalam Menentukan Calon Penerima Bantuan Program Keluarga Harapan Berbasis Web (Studi Kasus: Desa Tengguli Kecamatan Sajad)". Penelitian ini akan membuat sebuah aplikasi yang mempermudah dalam pengambilan dan seleksi data calon penerima bantuan PKH. Diharapkan dengan adanya aplikasi ini dapat membantu proses seleksi peserta penerima bantuan di Desa Tengguli Kecamatan Sajad dan memudahakan Peserta Calon Penerima bantuan dalam mendaftarkan diri.

\section{LANDASAN TEORI}

\subsection{Sistem Pendukung Keputusan}

Sistem pendukung keputusan merupakan implementasi dari teori-teori pengambilan keputusan yang telah diperkenalkan oleh ilmu-ilmu seperti operation research dan management science. Perbedaannya antara dahulu dengan sekarang terletak pada cara untuk mencari penyelesaian masalah yang dihadapi. Jika dahulu harus dilakukan perhitungan iterasi secara manual, saat ini komputer menawarkan kemampuannya untuk menyelesaikan persoalan yang sama dalam waktu relatif singkat. Sistem pendukung keputusan memberikan dukungan kepada seorang manajer atau kepala sekelompok manajer dalam memecah masalah semi terstruktur dengan memberikan informasi atau saran mengenai keputusan tertentu, informasi tersebut dapat dapat diberikan dalam bentuk laporan berkala, laporan khusus maupun model matematis [6].

Sistem pendukung keputusan adalah suatu sistem informasi berbasis komputer yang terdiri dari tiga kompoenen, yaitu: sistem bahasa, sistem pengetahuan dan sistem pemrosesan masalah. Sistem Pendukung Keputusan ini ditujukan untuk membantu dalam mengambil keputusan yang berkaitan dengan persoalan yang bersifat terstruktur atau tidak terstruktur. Ada banyak metode terkait sistem pendukung keputusan, salah satunya adalah metode Promethee. 


\subsection{Promethee}

Promethee adalah suatu metode penentuan urutan (prioritas) dalam analisis multikriteria. Masalah pokoknya adalah kesederhanaan, kejelasan, dan kestabilan. Dugaan dari dominasi kriteria yang digunakan dalam Promethee adalah penggunaan nilai dalam hubungan outranking. Penggunaan Promethee adalah menentukan dan menghasilkan rekomendasi dari beberapa alternatif [3]. Metode Promethee dalam memberikan rekomendasi calon penerima didalam sistem memiliki dasar-dasar untuk evaluasi data yang dapat lihat dalam Tabel 1 .

Tabel 1 Dasar Dasar Promethee

\begin{tabular}{|l|l|l|l|l|l|l|}
\hline & $f_{1}()$. & $f_{2}()$. & $\ldots \ldots$ & $f_{j}()$. & $\ldots \ldots$ & $f_{k}()$. \\
\hline$a_{1}$ & $f_{1}\left(a_{1}\right)$ & $f_{2}\left(a_{1}\right)$ & $\ldots \ldots$ & $f_{j}\left(a_{1}\right)$ & $\ldots \ldots$ & $f_{k}\left(a_{1}\right)$ \\
\hline$a_{2}$ & $f_{1}\left(a_{2}\right)$ & $f_{2}\left(a_{2}\right)$ & $\ldots \ldots$ & $f_{j}\left(a_{2}\right)$ & $\ldots \ldots$ & $f_{k}\left(a_{2}\right)$ \\
\hline$a_{i}$ & $f_{1}\left(a_{i}\right)$ & $f_{2}\left(a_{i}\right)$ & $\ldots \ldots$ & $f_{j}\left(a_{i}\right)$ & $\ldots \ldots$ & $f_{k}\left(a_{i}\right)$ \\
\hline$a_{n}$ & $f_{1}\left(a_{n}\right.$ & $f_{2}\left(a_{n}\right)$ & $\ldots \ldots$ & $f_{j}\left(a_{n}\right)$ & $\ldots \ldots$ & $f_{k}\left(a_{n}\right)$ \\
\hline
\end{tabular}

Keterangan:

$a_{1}, a_{2}, \ldots a_{n} \quad: n$ peserta potensial

$f_{1}, f_{2}, \ldots f_{j}, f_{k}: k$ kriteria evaluasi

\subsection{Langkah-langkah Perhitungan dalam Metode Promethee}

Pada metode Promethee memiliki langkah-langkah dalam proses perhitungannya. Langkah-langkah perhitungan dengan menggunakan metode Promethee adalah sebagai berikut [7]:

1. Menentukan jumlah peserta.

2. Menentukan jumlah kriteria.

3. Menentukan tipe preferensi untuk setiap kriteria yang paling cocok didasarkan pada data dan pertimbangan dari decision maker.

4. Tipe preferensi ini berjumlah enam (Tipe Usual, Tipe Quasi, Tipe Linear, Tipe Level, Tipe Linear Quasi dan Tipe Gaussian).

5. Tipe preferensi yang digunakan adalah Tipe Usual.

6. Perhitungan Entering Flow, Leaving Flow dan Net Flow.

7. Hasil pengurutan hasil dari perangkingan.

\subsection{Rekomendasi Fungsi Preferensi untuk Keperluan Aplikasi}

Promethee dapat disajikan dalam enam bentuk fungsi preferensi kriteria yang sering digunakan dalam proses perhitungannya, yaitu Tipe Usual, Tipe Quasi, Tipe Linear, Tipe Level, Tipe Linear Quasi dan Tipe Gaussian. Hal ini tentu saja tidak mutlak, tetapi bentuk ini cukup baik untuk beberapa kasus. Untuk memberikan gambaran yang lebih baik terhadap area yang tidak sama, dapat digunakan fungsi selisih nilai kriteria antar peserta $H(d)$ [2].

Pada penelitian ini preferensi yang digunakan adalah preferensi Tipe Usual, karena Tipe ini lebih cocok untuk diterapkan pada banyak kriteria. Untuk melihat kasus preferensi pada Tipe Usual, dapat digambarkan dalam seleksi calon penerima bantuan PKH. Satu peserta dengan peserta yang lain akan memiliki peringkat yang berbeda walaupun hanya memiliki selisih yang kecil, dan akan memiliki peringkat yang sama jika jumlah atau selisih nilai yang diperoleh sama. Persamaan Tipe Usual dapat dilihat pada pada Persamaan 1.

$$
H(d)= \begin{cases}0, & \text { jika } d \leq 0 \\ 1, & \text { jika } d>0\end{cases}
$$

Keterangan:

$H(d)$ : fungsi selisih kriteria peserta.

$d \quad$ : selisih nilai kriteria $\{d=f(a)-f(b)\}$

Persamaan 1 menjelaskan bahwa nilai $a$ dan $b$ akan bernilai 0 , jika dan hanya jika $f(a)$ memiliki nilai yang sama dengan nilai $f(b)$, apabila nilai $d$ pada masing-masing kriteria memiliki nilai negatif maka nilainya harus dibuat mutlak untuk mendapatkan nilai yang lebih baik. Fungsi $H(d)$ untuk preferensi ini disajikan pada Gambar 1.

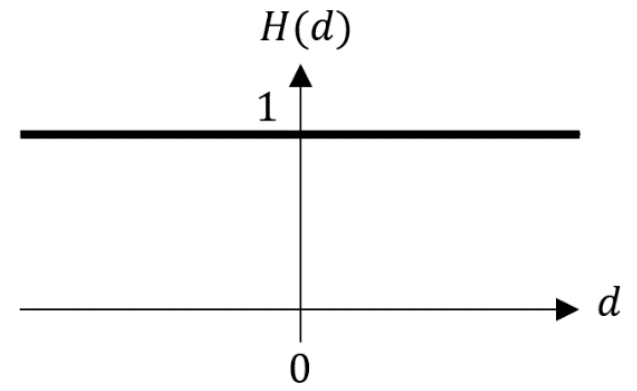

Gambar 1 Tipe Usual

Sumber: [4] 


\subsection{Arah dalam Grafik Nilai Outrangking}

Perangkingan yang digunakan dalam metode Promethee meliputi empat bentuk antara lain:

\subsubsection{Indeks Preferensi}

Indeks preferensi merupakan jumlah nilai preferensi dari perbandingan kriteria antara peserta yang satu dengan peserta lain. Nilai indeks preferensi yang mendekati satu merupakan nilai preferensi terbesar. Indeks preferensi multikriteria dapat dilihat dari Persamaan 2 sebagai berikut:

$$
\delta(a, b)=\sum_{i=1}^{n} \pi_{i} P_{i}(a, b): \forall a, b \in A
$$

Keterangan:

$\delta(a, b)$ : indeks preferensi peserta $a$ lebih baik dari peserta $b$

$\pi_{i} \quad$ : ukuran relatif dari kepentingan kriteria $f_{i}$

$P_{i}(a, b)$ : preferensi peserta $a$ terhadap peserta $b$

\subsubsection{Leaving Flow}

Leaving Flow adalah jumlah dari yang memiliki arah menjauh dari node $a$ dan hal ini merupakan pengukuran outrangking. Untuk setiap nilai node $a$ dalam grafik nilai outrangking ditentukan berdasarkan Leaving Flow. Adapun persamaannya pada Persamaan 3.

$$
\varphi^{+}(a)=\frac{1}{n-1} \sum_{x \in A} \delta(a, x)
$$

Keterangan:

$$
\begin{aligned}
& \varphi^{+}(a) \quad \text { : nilai Leaving Flow } \\
& \delta(a, x) \quad \text { : menunjukkan preferensi peserta } \\
& a \text { lebih baik dari } x . \\
& n \quad: \text { jumlah nilai. }
\end{aligned}
$$

\subsubsection{Entering Flow}

Entering Flow adalah jumlah dari yang memiliki arah mendekat dari node $a$ dan hal ini merupakan karakter pengukuran outrangking. Untuk setiap nilai node $a$ dalam grafik nilai outrangking ditentukan berdasarkan Entering Flow pada Persamaan 4.

$$
\varphi^{-}(a)=\frac{1}{n-1} \sum_{x \in A} \delta(a, x)
$$

Keterangan:

$$
\begin{array}{ll}
\varphi^{-}(a) & \text { : nilai Entering Flow } \\
\delta(a, x) & : \text { menunjukkan preferensi peserta } \\
& \text { a lebih baik dari } \mathrm{x} .
\end{array}
$$

$$
n \quad \text { : jumlah nilai. }
$$

\subsubsection{Net Flow}

Net Flow adalah hasil pengurangan dari nilai Leaving Flow dan Entering Flow yang sudah didapat pada persamaan 3 dan 4 . Sehingga pertimbangan dalam penentuan $\mathrm{Net}$ Flow diperoleh pada Persamaan 5.

$$
\varphi(a)=\varphi^{+}(a)-\varphi^{-}(a)
$$

Keterangan:

$$
\begin{array}{ll}
\varphi(a) & \text { : nilai Net Flow } \\
\varphi^{+}(a) & : \text { hasil Leaving Flow. } \\
\varphi^{-}(a) & \text { : hasil Entering Flow. }
\end{array}
$$

Semakin besar nilai Leaving Flow dan semakin kecil Entering Flow maka peserta tersebut memiliki kemungkinan dipilih yang semakin besar. Perangkingan dalam Promethee I dilakukan secara parsial, yaitu didasarkan pada nilai Entering Flow dan Leaving Flow. Sedangkan Promethee II termasuk perangkingan komplek karena didasarkan pada nilai Net Flow masingmasing peserta yaitu peserta dengan nilai $\mathrm{Net}$ Flow lebih tinggi menempati satu rangking yang lebih baik.

\section{METODE PENELITIAN}

Penelitian impelementasi metode Promethee ini dilakukan dengan melalui tahapan-tahapan, yaitu studi literatur, metode pengumpulan data, analisis kebutuhan, perancangan sistem, implementasi sistem dan pengujian. Semua tahapan yang digunakan dalam penelitian ini akan dijelaskan secara rinci, sebagai berikut:

\subsection{Studi Literatur}

Studi literatur yang dilakukan dalam penelitian ini adalah dengan mempelajari dan menggunakan referensi seperti jurnal, skripsi dan buku yang berkaitan dengan perhitungan dan metode promethee ataupun yang berkaitan dengan permasalahan yang diangkat pada penelitian ini.

\subsection{Pengumpulan Data}

Pengumpulan data calon penerima bantuan PKH di desa Tengguli yang terdiri dari 4 Dusun, yaitu: Dusun Sawang, Pelok, Pemidingan, dan Sajat dilakukan dengan cara memberikan kuesioner kepada calon penerima bantuan. Data yang diambil sebanyak 200 data keluarga. Oleh karena di Desa Tengguli ada 4 dusun, maka setiap dusun diambil 50 data keluarga calon penerima bantuan PKH. Data 
yang dikumpulkan sebagai berikut, yaitu: penghasilan, jumlah tabungan, luas bangunan, jenis lantai, jenis dinding, biaya pengobatan, jumlah makan perhari, sembako, sumber penerangan, sumber air bersih, alat memasak, jumlah tanggungan, usia lanjut, jumlah anak sekolah. penyandang disabilitas, ibu hamil/menyusui.

\subsection{Analisis Kebutuhan Sistem}

Analisa kebutuhan ini dibagi menjadi dua yaitu kebutuhan perangkat keras dan kebutuhan perangkat lunak sebagai berikut:

\subsubsection{Kebutuhan Perangkat Keras}

Kebutuhan perangkat keras menunjang proses pembuatan aplikasi dan penulisan dalam penelitian ini. Perangkat keras yang digunakan dalam pembuatan sistem ini adalah:

1. Prosesor Intel(R) Core(TM) i3-4005U

2. RAM $6 \mathrm{~GB}$

3. Hardisk $500 \mathrm{~GB}$

4. Monitor LCD 14 Inch

5. Keyboard dan Mouse Standard

\subsubsection{Kebutuhan Perangkat Lunak}

Kebutuhan perangkat lunak juga sangat diperlukan dalam pembuatan sistem ini karena perangkat lunak inilah yang dapat menerjemahkan bahasa mesin ke dalam bahasa yang bisa dipahami manusia. Kebutuhan perangkat lunak dalam sistem ini adalah:

1. Sistem Operasi Windows 10 Pro

2. Sublime Text Editor digunakan sebagai aplikasi pengetikan kode bahasa pemrograman.

3. Xampp (X, Apache, Mysql, PHP, Perl)

4. Google Chrome digunakan untuk mengakses halaman web.

5. Balsamiq Mock-Up digunakan untuk merancang tampilan sistem.

6. Microsoft Word digunakan untuk menulis laporan penelitian.

\subsection{Perancangan Sistem}

Perancangan sistem dimulai dengan merancang tabel untuk menyimpan data ke dalam basis data, membuat DFD untuk merancang aliran data dalam sistem ini, dan membuat ERD untuk mengetahui hubungan antar tabel, serta membuat rancangan antamuka aplikasi untuk memudahkan pengguna. Hasil rancangan ini akan digunakan sebagai acuan dalam mengimplementasikan perangkat lunak yang akan dibuat.

\subsection{Implementasi}

Pada bagian ini, Sistem akan dibuat dengan mengimplementasikan perancangan yang telah dibuat dan untuk data yang digunakan adalah data yang sudah dikumpulkan sebelumnya, serta pada proses implementasi inilah sebuah sistem selesai dibuat.

\subsection{Pengujian}

Pada bagian ini, sistem yang telah dibuat pada proses implementasi akan diuji menggunakan White Box untuk melihat sejauh mana sistem berfungsi sesuai dengan apa yang diharapkan pada tahan analisis kebutuhan maupun tahap perancangan.

\section{IMPLEMENTASI, PENGUJIAN DAN PEMBAHASAN}

\subsection{Implementasi Perhitungan}

Perhitungan manual ini dilakukan melalui beberapa tahapan yang mengikuti alur algoritma Promethee. Tahap pertama yang dilakukan adalah menyiapkan data. Data yang digunakan merupakan data asli yang didapatkan langsung saat pengambilan data. Data tersebut disajikan dalam bentuk tabel dimana peserta akan disimbolkan dengan huruf A1, A2, A3, A4, A5. Kemudian Kriterita disimbolkan dengan $\mathrm{K} 1, \mathrm{~K} 2, \mathrm{~K} 3$, sampai dengan K16. Tabel data peserta dapat dilihat pada Tabel 2.

Tabel 2 Data Peserta

\begin{tabular}{|c|c|c|c|c|c|c|c|c|c|c|c|c|c|c|c|c|c|}
\hline \multirow{2}{*}{ No } & \multirow{2}{*}{ Peserta } & \multicolumn{16}{|c|}{ Kriteria } \\
\hline & & K1 & $\mathrm{K} 2$ & K3 & K4 & K5 & K6 & K7 & K8 & K9 & K10 & K11 & K12 & K13 & K14 & K15 & K16 \\
\hline 1. & A1 & 5 & 5 & 2 & 2 & 1 & 4 & 1 & 2 & 1 & 2 & 3 & 3 & 1 & 4 & 1 & 1 \\
\hline 2. & A2 & 5 & 6 & 2 & 2 & 2 & 3 & 1 & 2 & 1 & 2 & 3 & 2 & 3 & 1 & 1 & 1 \\
\hline 3. & A3 & 4 & 5 & 4 & 2 & 2 & 4 & 1 & 2 & 1 & 2 & 1 & 2 & 2 & 3 & 1 & 1 \\
\hline 4. & A4 & 4 & 4 & 4 & 2 & 2 & 3 & 1 & 2 & 1 & 2 & 1 & 3 & 1 & 3 & 1 & 1 \\
\hline 5. & A5 & 5 & 6 & 5 & 2 & 2 & 4 & 1 & 2 & 1 & 2 & 1 & 2 & 1 & 2 & 1 & 1 \\
\hline
\end{tabular}


Tahap kedua mencari nilai $d$ yaitu perbandingan kriteria pada setiap data. Kemudian mencari nilai preferensi menggunakan tipe Usual dari nilai $d$ yang telah didapatkan. Jika nilai $d$ kurang dari atau sama dengan 0 maka nilai preferensinya bernilai 0 dan jika perbandingan lebih dari 0 maka nilai preferensinya 1 . Langkah-langkah mencari nilai preferensi menggunakan Persamaan (1):

$$
H(d)= \begin{cases}0, & \text { jika } d \leq 0 \\ 1, & \text { jikad }>0\end{cases}
$$

Setiap data akan dibandingkan nilai kriterianya untuk mencari nilai preferensi. Karena disini ada 5 data maka data yang pertama akan dibandingkan dengan empat data setelahnya. Setelah data pertama dibandingkan kemudian lanjut data kedua akan dibandingkan lagi dengan empat data lainnya, sampai dengan data terakhir. Berikut contoh perhitungannya: Data berpusat pada A1 (Tabel 1)

Pada kolom K1

$$
\begin{array}{ll}
d_{11} & =(\mathrm{A} 1, \mathrm{~K} 1)-(\mathrm{A} 1, \mathrm{~K} 1)=5-5=0 \\
H\left(d_{11}\right) & =0 \\
d_{21} & =(\mathrm{A} 1, \mathrm{~K} 1)-(\mathrm{A} 2, \mathrm{~K} 1)=5-5=0 \\
H\left(d_{21}\right) & =0 \\
d_{31} & =(\mathrm{A} 1, \mathrm{~K} 1)-(\mathrm{A} 3, \mathrm{~K} 1=5-4=1 \\
H\left(d_{31}\right) & =1 \\
d_{41} & =(\mathrm{A} 1, \mathrm{~K} 1)-(\mathrm{A} 4, \mathrm{~K} 1)=5-4=1 \\
H\left(d_{41}\right) & =1 \\
d_{51} & =(\mathrm{A} 1, \mathrm{~K} 1)-(\mathrm{A} 5, \mathrm{~K} 1)=5-5=0 \\
H\left(d_{51}\right) & =0
\end{array}
$$

Pada kolom K2

$$
\begin{array}{ll}
d_{12} & =(\mathrm{A} 1, \mathrm{~K} 2)-(\mathrm{A} 1, \mathrm{~K} 2)=5-5=0 \\
H\left(d_{12}\right) & =0 \\
d_{22} & =((\mathrm{A} 1, \mathrm{~K} 2)-\mathrm{A} 2, \mathrm{~K} 2)=5-6=-1 \\
H\left(d_{22}\right) & =0 \\
d_{32} & =(\mathrm{A} 1, \mathrm{~K} 2)-(\mathrm{A} 3, \mathrm{~K} 2)=5-5=0 \\
H\left(d_{32}\right) & =0 \\
d_{42} & =(\mathrm{A} 1, \mathrm{~K} 2)-(\mathrm{A} 4, \mathrm{~K} 2)=5-4=1 \\
H\left(d_{42}\right) & =1 \\
d_{52} & =(\mathrm{A} 1, \mathrm{~K} 2)-(\mathrm{A} 5, \mathrm{~K} 2)=5-6=-1 \\
H\left(d_{52}\right) & =0
\end{array}
$$

Pada kolom K16

$$
\begin{array}{ll}
d_{15} & =(\mathrm{A} 1, \mathrm{~K} 5)-(\mathrm{A} 1 \mathrm{~K} 5)=1-1=0 \\
H\left(d_{15}\right) & =0 \\
d_{25} & =(\mathrm{A} 1, \mathrm{~K} 5)-(\mathrm{A} 2, \mathrm{~K} 5)=1-1=0 \\
H\left(d_{25}\right) & =0 \\
d_{35} & =(\mathrm{A} 1, \mathrm{~K} 5)-(\mathrm{A} 3, \mathrm{~K} 5)=1-1=0 \\
H\left(d_{35}\right) & =0 \\
d_{45} & =(\mathrm{A} 1, \mathrm{~K} 5)-(\mathrm{A} 4, \mathrm{~K} 5)=1-1=0 \\
H\left(d_{45}\right) & =0
\end{array}
$$

$$
\begin{array}{ll}
d_{55} & =(\mathrm{A} 1, \mathrm{~K} 5)-(\mathrm{A} 5, \mathrm{~K} 5)=1-1=0 \\
H\left(d_{55}\right) & =0
\end{array}
$$

Data berpusat pada A2

Pada kolom K1

$$
\begin{array}{ll}
d_{11} & =(\mathrm{A} 2, \mathrm{~K} 1)-(\mathrm{A} 1, \mathrm{~K} 1)=5-5=0 \\
H\left(d_{11}\right) & =0 \\
d_{21} & =(\mathrm{A} 2, \mathrm{~K} 1)-(\mathrm{A} 2, \mathrm{~K} 1)=5-5=0 \\
H\left(d_{21}\right) & =0 \\
d_{31} & =(\mathrm{A} 2, \mathrm{~K} 1)-(\mathrm{A} 3, \mathrm{~K} 1)=5-4=1 \\
H\left(d_{31}\right) & =1 \\
d_{41} & =(\mathrm{A} 2, \mathrm{~K} 1)-(\mathrm{A} 4, \mathrm{~K} 1)=5-4=1 \\
H\left(d_{41}\right) & =1 \\
d_{51} & =(\mathrm{A} 2, \mathrm{~K} 1)-(\mathrm{A} 5, \mathrm{~K} 1)=5-5=0 \\
H\left(d_{51}\right) & =0
\end{array}
$$

Pada kolom K2

$$
\begin{array}{ll}
d_{12} & =(\mathrm{A} 2, \mathrm{~K} 2)-(\mathrm{A} 1, \mathrm{~K} 2)=6-5=1 \\
H\left(d_{12}\right) & =1 \\
d_{22} & =(\mathrm{A} 2, \mathrm{~K} 2)-(\mathrm{A} 2, \mathrm{~K} 2)=6-6=0 \\
H\left(d_{22}\right) & =0 \\
d_{32} & =(\mathrm{A} 2, \mathrm{~K} 2)-(\mathrm{A} 3, \mathrm{~K} 2)=6-5=1 \\
H\left(d_{32}\right) & =1 \\
d_{42} & =(\mathrm{A} 2, \mathrm{~K} 2)-(\mathrm{A} 4, \mathrm{~K} 2)=6-4=2 \\
H\left(d_{42}\right) & =1 \\
d_{52} & =(\mathrm{A} 2, \mathrm{~K} 2)-(\mathrm{A} 5, \mathrm{~K} 2)=6-6=0 \\
H\left(d_{52}\right) & =0
\end{array}
$$

Pada kolom K5

$$
\begin{array}{ll}
d_{15} & =(\mathrm{A} 2, \mathrm{~K} 5)-(\mathrm{A} 1, \mathrm{~K} 5)=1-1=0 \\
H\left(d_{15}\right) & =0 \\
d_{216} & =(\mathrm{A} 2, \mathrm{~K} 5)-(\mathrm{A} 2, \mathrm{~K} 5)=1-1=0 \\
H\left(d_{25}\right) & =0 \\
d_{35} & =(\mathrm{A} 2, \mathrm{~K} 5)-(\mathrm{A} 3, \mathrm{~K} 5)=1-1=0 \\
H\left(d_{35}\right) & =0 \\
d_{45} & =(\mathrm{A} 2, \mathrm{~K} 5)-(\mathrm{A} 4, \mathrm{~K} 5)=1-1=0 \\
H\left(d_{45}\right) & =0 \\
d_{55} & =(\mathrm{A} 2, \mathrm{~K} 5)-(\mathrm{A} 5, \mathrm{~K} 5)=1-1=0 \\
H\left(d_{55}\right) & =0
\end{array}
$$

Data berpusat pada A3

Pada kolom K1

$$
\begin{array}{ll}
d_{11} & =(\mathrm{A} 3, \mathrm{~K} 1)-(\mathrm{A} 1, \mathrm{~K} 1)=4-5=-1 \\
H\left(d_{11}\right) & =0 \\
d_{21} & =(\mathrm{A} 3, \mathrm{~K} 1)-(\mathrm{A} 2, \mathrm{~K} 1)=4-5=-1 \\
H\left(d_{21}\right) & =0 \\
d_{31} & =(\mathrm{A} 3, \mathrm{~K} 1)-(\mathrm{A} 3, \mathrm{~K} 1)=4-4=0 \\
H\left(d_{31}\right) & =0 \\
d_{41} & =(\mathrm{A} 3, \mathrm{~K} 1)-(\mathrm{A} 4, \mathrm{~K} 1)=4-4=0 \\
H\left(d_{41}\right) & =0 \\
d_{51} & =(\mathrm{A} 3, \mathrm{~K} 1)-(\mathrm{A} 5, \mathrm{~K} 1)=4-5=-1 \\
H\left(d_{51}\right) & =0
\end{array}
$$


Pada kolom K2

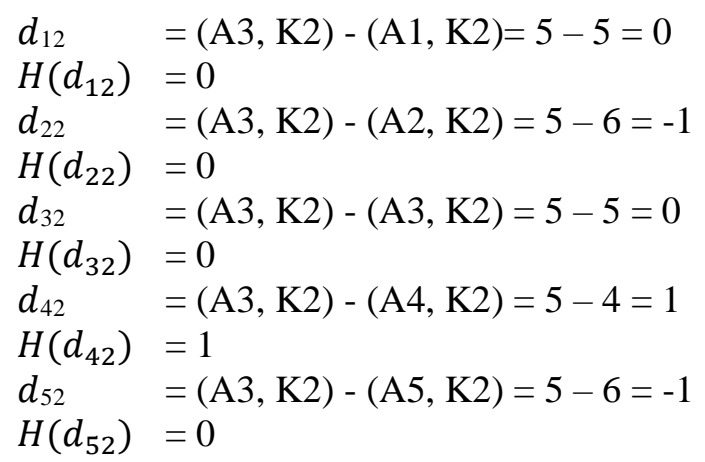

Pada kolom K5

$d_{15}=(\mathrm{A} 3, \mathrm{~K} 5)-(\mathrm{A} 1, \mathrm{~K} 5)=1-1=0$ $H\left(d_{15}\right)=0$

$d_{25}=(\mathrm{A} 3, \mathrm{~K} 5)-(\mathrm{A} 2, \mathrm{~K} 5)=1-1=0$ $H\left(d_{25}\right)=0$

$d_{35}=(\mathrm{A} 3, \mathrm{~K} 5)-(\mathrm{A} 3, \mathrm{~K} 5)=1-1=0$

$H\left(d_{35}\right)=0$

$d_{45}=(\mathrm{A} 3, \mathrm{~K} 5)-(\mathrm{A} 4, \mathrm{~K} 5)=1-1=0$

$H\left(d_{45}\right)=0$

$d_{55}=(\mathrm{A} 3, \mathrm{~K} 5)-(\mathrm{A} 5, \mathrm{~K} 5)=1-1=0$

$H\left(d_{55}\right)=0$

Data berpusat pada A4

Pada kolom K1

$d_{11}=(\mathrm{A} 4, \mathrm{~K} 1)-(\mathrm{A} 1, \mathrm{~K} 1)=4-5=-1$

$H\left(d_{11}\right)=0$

$d_{21}=(\mathrm{A} 4, \mathrm{~K} 1)-(\mathrm{A} 2, \mathrm{~K} 1) 4-5=-1$

$H\left(d_{21}\right)=0$

$d_{31}=(\mathrm{A} 4, \mathrm{~K} 1)-(\mathrm{A} 3, \mathrm{~K} 1)=4-4=0$

$H\left(d_{31}\right)=0$

$d_{41}=(\mathrm{A} 4, \mathrm{~K} 1)-(\mathrm{A} 4, \mathrm{~K} 1)=4-4=0$

$H\left(d_{41}\right)=0$

$d_{51}=(\mathrm{A} 4, \mathrm{~K} 1)-(\mathrm{A} 5, \mathrm{~K} 1)=4-5=-1$

$H\left(d_{51}\right)=0$

Pada kolom K2

$d_{12}=(\mathrm{A} 4, \mathrm{~K} 2)-(\mathrm{A} 1, \mathrm{~K} 2)=4-5=-1$ $H\left(d_{12}\right)=0$

$d_{22}=(\mathrm{A} 4, \mathrm{~K} 2)-(\mathrm{A} 2, \mathrm{~K} 2)=4-6=-2$

$H\left(d_{22}\right)=0$

$d_{32}=(\mathrm{A} 4, \mathrm{~K} 2)-(\mathrm{A} 3, \mathrm{~K} 2)=4-5=-1$

$H\left(d_{32}\right)=0$

$d_{42}=(\mathrm{A} 4, \mathrm{~K} 2)-(\mathrm{A} 4, \mathrm{~K} 2)=4-4=0$

$H\left(d_{42}\right)=0$

$d_{52}=(\mathrm{A} 4, \mathrm{~K} 2)-(\mathrm{A} 5, \mathrm{~K} 2)=4-6=-2$

$H\left(d_{52}\right)=0$

Pada kolom K5

$$
\begin{array}{ll}
d_{15} & =(\mathrm{A} 4, \mathrm{~K} 5)-(\mathrm{A} 1, \mathrm{~K} 5)=1-1=0 \\
H\left(d_{15}\right) & =0 \\
d_{25} & =(\mathrm{A} 4, \mathrm{~K} 5)-(\mathrm{A} 2, \mathrm{~K} 5)=1-1=0
\end{array}
$$

$$
\begin{array}{ll}
H\left(d_{25}\right) & =0 \\
d_{35} & =(\mathrm{A} 4, \mathrm{~K} 5)-(\mathrm{A} 3, \mathrm{~K} 5)=1-1=0 \\
H\left(d_{35}\right) & =0 \\
d_{45} & =(\mathrm{A} 4, \mathrm{~K} 5)-(\mathrm{A} 4, \mathrm{~K} 5)=1-1=0 \\
H\left(d_{45}\right) & =0 \\
d_{55} & =(\mathrm{A} 4, \mathrm{~K} 5)-(\mathrm{A} 5, \mathrm{~K} 5)=1-1=0 \\
H\left(d_{55}\right) & =0
\end{array}
$$

Data berpusat pada A5

$$
\begin{aligned}
& \text { Pada kolom K1 } \\
& d_{11}=(\mathrm{A} 5, \mathrm{~K} 1)-(\mathrm{A} 1, \mathrm{~K} 1)=5-5=0 \\
& H\left(d_{11}\right)=0 \\
& d_{21}=(\mathrm{A} 5, \mathrm{~K} 1)-(\mathrm{A} 2, \mathrm{~K} 1)=5-5=0 \\
& H\left(d_{21}\right)=0 \\
& d_{31}=(\mathrm{A} 5, \mathrm{~K} 1)-(\mathrm{A} 3, \mathrm{~K} 1)=5-4=1 \\
& H\left(d_{31}\right)=1 \\
& d_{41}=(\mathrm{A} 5, \mathrm{~K} 1)-(\mathrm{A} 4, \mathrm{~K} 1)=5-4=1 \\
& H\left(d_{41}\right)=1 \\
& d_{51}=(\mathrm{A} 5, \mathrm{~K} 1)-(\mathrm{A} 5, \mathrm{~K} 1)=5-5=0 \\
& H\left(d_{51}\right)=0
\end{aligned}
$$

Pada kolom K2

$$
\begin{array}{ll}
d_{12} & =(\mathrm{A} 5, \mathrm{~K} 2)-(\mathrm{A} 1, \mathrm{~K} 2)=6-5=1 \\
H\left(d_{12}\right) & =1 \\
d_{22} & =(\mathrm{A} 5, \mathrm{~K} 2)-(\mathrm{A} 2, \mathrm{~K} 2)=6-6=0 \\
H\left(d_{22}\right) & =0 \\
d_{32} & =(\mathrm{A} 5, \mathrm{~K} 2)-(\mathrm{A} 3, \mathrm{~K} 2)=6-5=1 \\
H\left(d_{32}\right) & =1 \\
d_{42} & =(\mathrm{A} 5, \mathrm{~K} 2)-(\mathrm{A} 4, \mathrm{~K} 2)=6-4=2 \\
H\left(d_{42}\right) & =1 \\
d_{52} & =(\mathrm{A} 5, \mathrm{~K} 2)-(\mathrm{A} 5, \mathrm{~K} 2)=6-6=0 \\
H\left(d_{52}\right) & =0
\end{array}
$$

$$
\begin{array}{ll}
\begin{array}{l}
\text { Pada kolom K5 } \\
d_{15}
\end{array} & =(\mathrm{A} 5, \mathrm{~K} 5)-(\mathrm{A} 1, \mathrm{~K} 5)=1-1=0 \\
H\left(d_{15}\right) & =0 \\
d_{25} & =(\mathrm{A} 5, \mathrm{~K} 5)-(\mathrm{A} 2, \mathrm{~K} 5)=1-1=0 \\
H\left(d_{25}\right) & =0 \\
d_{35} & =(\mathrm{A} 5, \mathrm{~K} 5)-(\mathrm{A} 3, \mathrm{~K} 5)=1-1=0 \\
H\left(d_{316}\right) & =0 \\
d_{45} & =(\mathrm{A} 5, \mathrm{~K} 5)-(\mathrm{A} 4, \mathrm{~K} 5)=1-1=0 \\
H\left(d_{45}\right) & =0 \\
d_{55} & =(\mathrm{A} 5, \mathrm{~K} 5)-(\mathrm{A} 5, \mathrm{~K} 5)=1-1=0 \\
H\left(d_{55}\right) & =0
\end{array}
$$

Setelah data yang berpusat pada A1 selesai, kemudian perhitungan dilanjutkan dengan data berpusat pada A2, kemudian data berpusat pada A3, terakhir data berpusat pada A5. Nilai preferensi data peserta dapat dilihat pada Tabel 3, Tabel 4, Tabel 5, Tabel 6. 
Tabel 3 Preferensi Data yang Berpusat pada A1

\begin{tabular}{|c|c|c|c|c|c|c|c|c|c|c|c|c|}
\hline \multirow{3}{*}{ No } & \multirow{3}{*}{$\begin{array}{c}\text { Nam } \\
\text { a }\end{array}$} & \multicolumn{11}{|c|}{ A1 } \\
\hline & & \multicolumn{2}{|c|}{ K1 } & \multicolumn{2}{|c|}{$\mathrm{K} 2$} & \multicolumn{2}{|c|}{ K3 } & \multicolumn{2}{|c|}{ K4 } & $\ldots$ & \multicolumn{2}{|c|}{ K16 } \\
\hline & & $\mathrm{d} 1$ & $\mathrm{H}(\mathrm{d}) 1$ & $\mathrm{~d} 2$ & $\mathrm{H}(\mathrm{d}) 2$ & $\mathrm{~d} 3$ & $\mathrm{H}(\mathrm{d}) 3$ & $\mathrm{~d} 4$ & $\mathrm{H}(\mathrm{d}) 4$ & $\ldots$ & d16 & $\mathrm{H}(\mathrm{d}) 16$ \\
\hline 1. & A1 & 0 & 0 & 0 & 0 & 0 & 0 & 0 & 0 & $\ldots$ & 0 & 0 \\
\hline 2. & A2 & 0 & 0 & -1 & 0 & 0 & 0 & 0 & 0 & $\ldots$ & 0 & 0 \\
\hline 3. & A3 & 1 & 1 & 0 & 0 & -2 & 0 & 0 & 0 & $\ldots$ & 0 & 0 \\
\hline 4. & A4 & 1 & 1 & 1 & 1 & -2 & 0 & 0 & 0 & $\ldots$ & 0 & 0 \\
\hline 5. & A5 & 0 & 0 & -1 & 0 & -3 & 0 & 0 & 0 & $\ldots$ & 0 & 0 \\
\hline
\end{tabular}

Tabel 4 Preferensi Data yang Berpusat pada A2

\begin{tabular}{|c|c|c|c|c|c|c|c|c|c|c|c|c|}
\hline \multirow{3}{*}{ No } & \multirow{3}{*}{ Nama } & \multicolumn{11}{|c|}{ A2 } \\
\hline & & \multicolumn{2}{|c|}{$\mathrm{K} 1$} & \multicolumn{2}{|c|}{$\mathrm{K} 2$} & \multicolumn{2}{|c|}{$\mathrm{K} 3$} & \multicolumn{2}{|c|}{ K4 } & $\ldots$ & \multicolumn{2}{|c|}{ K16 } \\
\hline & & d1 & $\mathrm{H}(\mathrm{d}) 1$ & $\mathrm{~d} 2$ & $\mathrm{H}(\mathrm{d}) 2$ & $\mathrm{~d} 3$ & $\mathrm{H}(\mathrm{d}) 3$ & $\mathrm{~d} 4$ & $\mathrm{H}(\mathrm{d}) 4$ & $\ldots$ & d16 & $\mathrm{H}(\mathrm{d}) 16$ \\
\hline 1. & A1 & 0 & 0 & 1 & 1 & 0 & 0 & 0 & 0 & $\ldots$ & 0 & 0 \\
\hline 2. & A2 & 0 & 0 & 0 & 0 & 0 & 0 & 0 & 0 & $\ldots$ & 0 & 0 \\
\hline 3. & A3 & 1 & 1 & 1 & 1 & -2 & 0 & 0 & 0 & $\ldots$ & 0 & 0 \\
\hline 4. & A4 & 1 & 1 & 2 & 1 & -2 & 0 & 0 & 0 & $\ldots$ & 0 & 0 \\
\hline 5. & A5 & 0 & 0 & 0 & 0 & -3 & 0 & 0 & 0 & $\ldots$ & 0 & 0 \\
\hline
\end{tabular}

Tabel 5 Preferensi Data yang Berpusat pada A3

\begin{tabular}{|c|c|c|c|c|c|c|c|c|c|c|c|c|}
\hline \multirow{3}{*}{ No } & \multirow{3}{*}{ Nama } & \multicolumn{11}{|c|}{ A3 } \\
\hline & & \multicolumn{2}{|c|}{$\mathrm{K} 1$} & \multicolumn{2}{|c|}{$\mathrm{K} 2$} & \multicolumn{2}{|c|}{ K3 } & \multicolumn{2}{|c|}{ K4 } & $\ldots$ & \multicolumn{2}{|c|}{ K16 } \\
\hline & & $\mathrm{d} 1$ & $\mathrm{H}(\mathrm{d}) 1$ & $\mathrm{~d} 2$ & $\mathrm{H}(\mathrm{d}) 2$ & $\mathrm{~d} 3$ & $\mathrm{H}(\mathrm{d}) 3$ & $\mathrm{~d} 4$ & $\mathrm{H}(\mathrm{d}) 4$ & $\ldots$ & $\mathrm{d} 16$ & $\mathrm{H}(\mathrm{d}) 16$ \\
\hline 1. & A1 & -1 & 0 & 0 & 0 & 2 & 1 & 0 & 0 & $\ldots$ & 0 & 0 \\
\hline 2. & A2 & -1 & 0 & -2 & 0 & 2 & 1 & 0 & 0 & $\ldots$ & 0 & 0 \\
\hline 3. & A3 & 0 & 0 & 0 & 0 & 0 & 0 & 0 & 0 & $\ldots$ & 0 & 0 \\
\hline 4. & A4 & 0 & 0 & 1 & 1 & 0 & 0 & 0 & 0 & $\ldots$ & 0 & 0 \\
\hline 5. & A5 & -1 & 0 & -1 & 0 & -1 & 0 & 0 & 0 & $\ldots$ & 0 & 0 \\
\hline
\end{tabular}

Tabel 6 Preferensi Data yang Berpusat pada A4

\begin{tabular}{|c|c|c|c|c|c|c|c|c|c|c|c|c|}
\hline \multirow{3}{*}{ No } & \multirow{3}{*}{ Nama } & \multicolumn{11}{|c|}{ A4 } \\
\hline & & \multicolumn{2}{|c|}{ K1 } & \multicolumn{2}{|c|}{ K2 } & \multicolumn{2}{|c|}{ K3 } & \multicolumn{2}{|c|}{ K4 } & $\ldots$ & \multicolumn{2}{|c|}{ K16 } \\
\hline & & $\mathrm{d} 1$ & $\mathrm{H}(\mathrm{d}) 1$ & $\mathrm{~d} 2$ & $\mathrm{H}(\mathrm{d}) 2$ & $\mathrm{~d} 3$ & $\mathrm{H}(\mathrm{d}) 3$ & $\mathrm{~d} 4$ & $\mathrm{H}(\mathrm{d}) 4$ & $\ldots$ & $\mathrm{d} 16$ & $\mathrm{H}(\mathrm{d}) 16$ \\
\hline 1. & A1 & -1 & 0 & -1 & 0 & 2 & 1 & 0 & 0 & $\ldots$ & 0 & 0 \\
\hline 2. & A2 & -1 & 0 & -2 & 0 & 2 & 1 & 0 & 0 & $\ldots$ & 0 & 0 \\
\hline 3. & A3 & 0 & 0 & -1 & 0 & 0 & 0 & 0 & 0 & $\ldots$ & 0 & 0 \\
\hline 4. & $\mathrm{~A} 4$ & 0 & 0 & 0 & 0 & 0 & 0 & 0 & 0 & $\ldots$ & 0 & 0 \\
\hline 5. & A5 & -1 & 0 & -2 & 0 & -1 & 0 & 0 & 0 & $\ldots$ & 0 & 0 \\
\hline
\end{tabular}

Tabel 7 Preferensi Data yang Berpusat pada A5

\begin{tabular}{|c|c|c|c|c|c|c|c|c|c|c|c|c|}
\hline \multirow{3}{*}{ No } & \multirow{3}{*}{ Nama } & \multicolumn{11}{|c|}{ A5 } \\
\hline & & \multicolumn{2}{|c|}{ K1 } & \multicolumn{2}{|r|}{$\mathrm{K} 2$} & \multicolumn{2}{|c|}{ K3 } & \multicolumn{2}{|c|}{ K4 } & $\ldots$ & \multicolumn{2}{|c|}{ K16 } \\
\hline & & $\mathrm{d} 1$ & $\mathrm{H}(\mathrm{d}) 1$ & $\mathrm{~d} 2$ & $\mathrm{H}(\mathrm{d}) 2$ & $\mathrm{~d} 3$ & $\mathrm{H}(\mathrm{d}) 3$ & $\mathrm{~d} 4$ & $\mathrm{H}(\mathrm{d}) 4$ & $\ldots$ & d16 & $\mathrm{H}(\mathrm{d}) 16$ \\
\hline 1. & A1 & 0 & 0 & 1 & 1 & 3 & 1 & 0 & 0 & $\ldots$ & 0 & 0 \\
\hline 2. & A2 & 0 & 0 & 0 & 0 & 3 & 1 & 0 & 0 & $\ldots$ & 0 & 0 \\
\hline
\end{tabular}




\begin{tabular}{|c|c|c|c|c|c|c|c|c|c|c|c|c|}
\hline \multirow{3}{*}{ No } & \multirow{3}{*}{ Nama } & \multicolumn{11}{|c|}{ A5 } \\
\hline & & \multicolumn{2}{|c|}{ K1 } & \multicolumn{2}{|c|}{$\mathrm{K} 2$} & \multicolumn{2}{|c|}{ K3 } & \multicolumn{2}{|c|}{ K4 } & $\ldots$ & \multicolumn{2}{|c|}{ K16 } \\
\hline & & $\mathrm{d} 1$ & $\mathrm{H}(\mathrm{d}) 1$ & $\mathrm{~d} 2$ & $\mathrm{H}(\mathrm{d}) 2$ & $\mathrm{~d} 3$ & $\mathrm{H}(\mathrm{d}) 3$ & $\mathrm{~d} 4$ & $\mathrm{H}(\mathrm{d}) 4$ & $\ldots$ & d16 & $\mathrm{H}(\mathrm{d}) 16$ \\
\hline 3. & A3 & 1 & 1 & 1 & 1 & 1 & 1 & 0 & 0 & $\ldots$ & 0 & 0 \\
\hline 4. & A4 & 1 & 1 & 2 & 1 & 1 & 1 & 0 & 0 & $\ldots$ & 0 & 0 \\
\hline 5. & A5 & 0 & 0 & 0 & 0 & 0 & 0 & 0 & 0 & $\ldots$ & 0 & 0 \\
\hline
\end{tabular}

Tahap ketiga mencari nilai indeks preferensi. Nilai indeks preferensi didapat dari jumlah nilai preferensi. Mendapatkan nilai indeks preferensi dengan cara menjumlahkan nilai preferensi sebelumnya, kemudian membaginya dengan jumlah kriteria yang ada yaitu 16 kriteria. Mencari nilai indeks preferensi menggunakan Persamaan 2. Hasil dari indeks preferensi yang diapatkan dapat dilihat pada Tabel 8.

$$
\delta(a, b)=\sum_{i=1}^{n} \pi_{i} P_{i}(a, b): \forall a, b
$$

$\in A$

Dalam kasus ini $\pi_{i}$ tetap $\left(\frac{1}{16}\right)$, karena terdapat 16 kriteria, dan semua kriteria mempunyai kepentingan yang sama.

Sehingga Persamaan 2 dapat diubah menjadi:

$$
\delta(a, b)=\pi_{i} \sum_{i=1}^{n} P_{i}(a, b): \forall a, b
$$

Nilai indeks preferensi dengan data yang berpusat pada $\mathrm{A} 1$

$$
\begin{gathered}
\delta(A 1, A 1)=\frac{1}{16}(0+0+0+0+0+0+0+0+0+0+0 \\
+0+0+0+0+0)=0 \\
\delta(A 1, A 2)=\frac{1}{16}(0+0+0+0+0+1+0+0+0+0+0+ \\
1+0+1+0+0)=0,1875 \\
\delta(A 1, A 3)=\frac{1}{16}(1+0+0+0+0+0+0+0+0+0+1+ \\
1+0+1+0+0)=0,25 \\
\delta(A 1, A 4)=\frac{1}{16} \begin{array}{l}
(1+1+0+0+0+1+0+0+0+0+1+ \\
0+0+1+0+0)=0,3125
\end{array} \\
\delta(A 1, A 5)=\frac{1}{16}(0+1+1+0+1+0+0+0+0+0+0+ \\
0+0+0+0+0)=0,1875
\end{gathered}
$$

Nilai indeks preferensi dengan data yang berpusat pada $\mathrm{A} 2$

$\delta(A 2, A 1)=\frac{1}{16}(0+1+0+0+1+0+0+0+0+0+0+$

$$
\begin{aligned}
& 1+0+0+0+0)=0,1875 \\
& \delta(A 2, A 2)=\frac{1}{16}(0+0+0+0+0+0+0+0+0+0+0+ \\
& 0+0+0+0+0)=0
\end{aligned}
$$

$$
\begin{gathered}
\delta(A 2, A 3)=\frac{1}{16}(1+1+0+0+0+0+0+0+0+1+0+ \\
1+0+0+0+0)=0,25 \\
\delta(A 2, A 4)=\frac{1}{16}(1+1+0+0+0+0+0+0+0+1+0+ \\
1+0+0+0+0)=0,25 \\
\delta(A 2, A 5)=\frac{1}{16}(0+0+1+0+0+1+0+0+0+0+0+ \\
0+0+1+0+0)=0,1875
\end{gathered}
$$

Nilai indeks preferensi dengan data yang berpusat pada $\mathrm{A} 3$

$$
\begin{gathered}
\delta(A 3, A 1)=\frac{1}{16}(0+0+1+0+1+0+0+0+0+0+0+ \\
0+1+0+0+0)=0,1875 \\
\delta(A 3, A 2)=\frac{1}{16} \begin{array}{c}
(0+0+1+0+0+1+0+0+0+0+0+ \\
0+0+1+0+0)=0,1875
\end{array} \\
\delta(A 3, A 3)=\frac{1}{16}(0+0+0+0+0+0+0+0+0+0+0+ \\
0+0+0+0+0)=0 \\
\delta(A 3, A 4)=\frac{1}{16}(0+1+0+0+0+1+0+0+0+0+0+ \\
0+1+0+0+0)=0,1875 \\
\delta(A 3, A 5)=\frac{1}{16}(1+1+1+0+0+0+0+0+0+0+0+ \\
0+0+0+0+0)=0,1875
\end{gathered}
$$

Nilai indeks preferensi dengan data yang berpusat pada $\mathrm{A} 4$

$$
\begin{gathered}
\delta(A 4, A 1)=\frac{1}{16}(0+0+1+0+1+0+0+0+0+0+0+ \\
0+0+0+0+0)=0,125 \\
\delta(A 4, A 2)=\frac{1}{16}(0+0+1+0+0+0+0+0+0+0+0+ \\
1+0+1+0+0)=0,1875 \\
\delta(A 4, A 3)=\frac{1}{16}(0+0+0+0+0+0+0+0+0+0+0+ \\
0+1+0+0+0)=0,1875 \\
\delta(A 4, A 4)=\frac{1}{16}(0+0+0+0+0+0+0+0+0+0+0+0 \\
+0+0+0+0)=0 \\
\delta(A 4, A 5)=\frac{1}{16}(1+1+1+0+0+1+0+0+0+0+0+ \\
0+0+0+0+0)=0,125
\end{gathered}
$$

Nilai indeks preferensi dengan data yang berpusat pada $\mathrm{A} 200$

$$
\begin{aligned}
\delta(A 200, A 1)= & \frac{1}{16}(0+0+0+0+0+0+0+0+0+0+ \\
& 1+1+0+1+0+0)=0,1875 \\
\delta(A 200, A 2)= & \frac{1}{16}(0+0+0+0+0+0+0+0+0+0+ \\
& 1+0+1+0+0+0)=0,125
\end{aligned}
$$




$$
\begin{aligned}
\delta(A 200, A 3)= & \frac{1}{16}(0+0+0+0+0+0+0+0+0+0+ \\
& 0+0+1+1+0+0)=0,125 \\
\delta(A 200, A 4)= & \frac{1}{16}(0+0+0+0+0+0+0+0+0+0+ \\
& 0+1+0+1+0+0)=0,125
\end{aligned}
$$

$\delta(A 200, A 5)=\frac{1}{16}(0+0+0+0+0+0+0+0+0+0+$

$0+0+0+0+0+0)=0$

Tabel 8 Indeks Preferensi

\begin{tabular}{|l|l|c|c|c|c|c|}
\hline \multicolumn{1}{|c|}{ No } & Nama & A1 & A2 & A3 & A4 & A5 \\
\hline 1. & A1 & 0 & 0,1875 & 0,1875 & 0,125 & 0,1875 \\
\hline 2. & A2 & 0,1875 & 0 & 0,1875 & 0,1875 & 0,1875 \\
\hline 3. & A3 & 0,25 & 0,25 & 0 & 0,0625 & 0,1875 \\
\hline 4. & A4 & 0,3125 & 0,25 & 0,1875 & 0 & 0,125 \\
\hline 5. & A5 & 0,1875 & 0,125 & 0,125 & 0,125 & 0 \\
\hline
\end{tabular}

Kemudian dilakukan tahap keempat, setelah nilai indeks preferensinya kemudian dilanjutkan dengan perhitungan mencari nilai Leaving Flow dengan menggunakan Persamaan 3. Dimana untuk mendapatkan nilai Leaving Flow adalah menjumlahkan nilai indeks preferensi secara vertikal kemudian membaginya dengan jumlah data yang ada dikurang 1.

$$
\begin{aligned}
& \varphi^{+}(a)=\frac{1}{n-1} \sum_{x \in A} \delta(a, x) \\
& L F(A 1)=\frac{1}{5-1} \begin{array}{l}
(0+0,1875+0,25+0,3125+ \\
0,1875)=0,234375
\end{array} \\
& L F(A 2)=\frac{1}{5-1} \begin{array}{l}
(0,1875+0+0,25+0,25+0,125) \\
=0,203125
\end{array} \\
& L F(A 3)=\frac{1}{5-1} \begin{array}{l}
(0,1875+0,1875+0+0,1875+ \\
0,125)=0,171875
\end{array} \\
& L F(A 4)=\frac{1}{5-1} \begin{array}{l}
(0,125+0,1875+0,0625+0+ \\
0,125)=0,125
\end{array} \\
& L F(A 5)=\frac{1}{5-1} \quad \begin{array}{l}
(0,1875+0,1875+0,1875+ \\
0,125+0)=0,171875
\end{array}
\end{aligned}
$$

Setelah nilai Leaving Flow didapatkan, selanjutnya menghitung nilai Entering Flow dengan menggunakan Persamaan 4. Dimana untuk mendapatkan nilai Entering Flow adalah menjumlahkan nilai indeks preferensi secara horizontal kemudian membaginya dengan jumlah data yang ada dikurang 1 .

$$
\begin{gathered}
\varphi^{-}(a)=\frac{1}{n-1} \sum_{x \in A} \delta(a, x) \\
E F(A 1)=\frac{1}{5-1} \quad \begin{array}{l}
(0+0,1875+0,1875+0,125+ \\
0,1875)=0,171875
\end{array} \\
E F(A 2)=\frac{1}{5-1} \begin{array}{l}
(0,1875+0+0,1875+0,1875+ \\
0,1875)=0,1875
\end{array} \\
E F(A 3)=\frac{1}{5-1}(0,25+0,25+0+0,0625+0,1875) \\
\begin{array}{ll}
=0,1875 \\
E F(A 4)=\frac{1}{5-1} & (0,3125+0,25+0,1875+0+ \\
0,1875)=0,21875
\end{array} \\
E F(A 5)=\frac{1}{5-1} \quad \begin{array}{l}
(0,1875+0,1875+0,1875+0+0 \\
125+0)=0,140625
\end{array}
\end{gathered}
$$

Setelah nilai Leaving Flow dan Entering Flow didapatkan, selanjutnya menghitung nilai Net Flow dengan menggunakan Persamaan 5. Dimana untuk mendapatkan nilai Net Flow adalah dengan mengurangkan nilai Leaving Flow dengan Entering Flow.

$$
\begin{aligned}
& \varphi(a)=\varphi^{+}(a)-\varphi^{-}(a) \\
& N F(A 1)=0,234375-0,171875=0,0625 \\
& N F(A 2)=0,203125-0,1875=0,015625 \\
& N F(A 3)=0,171875-0,1875=-0,015625 \\
& N F(A 4)=0,125-0,21875=-0,09375 \\
& N F(200)=0,171875-0,140625=0,03125
\end{aligned}
$$

Hasil dari perhitungan dalam mencari nilai Leaving Flow, Entering Flow, dan Net Flow dapat dilihat pada Tabel 9.

Tabel 9 Perhitungan Promethee

\begin{tabular}{|l|l|c|c|c|c|}
\hline No & \multicolumn{1}{|c|}{ Nama } & $\begin{array}{c}\text { Nilai Leaving } \\
\text { Flow }\end{array}$ & $\begin{array}{c}\text { Nilai Entering } \\
\text { Flow }\end{array}$ & Nilai Net Flow & Rangking \\
\hline 1. & A1 & 0,234375 & 0,171875 & 0,0625 & 1 \\
\hline 2. & A2 & 0,203125 & 0,1875 & 0,015625 & 3 \\
\hline 3. & A3 & 0,171875 & 0,1875 & $-0,015625$ & 4 \\
\hline 4. & A4 & 0,125 & 0,21875 & $-0,09375$ & 5 \\
\hline
\end{tabular}




\begin{tabular}{|l|cc|c|c|c|c|}
\hline No & Nama & $\begin{array}{c}\text { Nilai Leaving } \\
\text { Flow }\end{array}$ & $\begin{array}{c}\text { Nilai Entering } \\
\text { Flow }\end{array}$ & Nilai Net Flow & Rangking \\
\hline 5. & A5 & 0,171875 & 0,140625 & 0,03125 & 2 \\
\hline
\end{tabular}

Berdasarkan data dari Tabel 8 nilai dari hasil rangking Net Flow didapatkan bahwa peserta dengan nama A5 memperoleh rangking 1 dengan nilai Net Flow 0,0625.

\subsection{Pengujian}

Pengujian sistem ini dilakukan dengan menggunakan pengujian White Box, dimana pengujian ini berdasarkan pada masing-masing pengguna, untuk mengetahui fungsi dari logika yang digunakan apakah sudah sesuai dengan rancangan yang telah dibuat.

\subsection{Pembahasan}

Pengujian dilakukan dengan mencari rata-rata nilai Net Flow pada masing-masing Dusun yaitu: Dusun Pelok, Dusun Sawang,
Dusun Pemidingan, Dusun Sajat. Nilai Net Flow adalah tolok ukur tingkat kemiskinan pada masing-masing Dusun. Semakin besar nilai Net Flow yang diperoleh semakin tinggi pula tingkat kemiskinan, sebaliknya semakin kecil nilai Net Flow yang diperoleh semakin rendah pula tingkat kemiskinannya.

Kuota bantuan yang akan diberikan pada Desa Tengguli sebanyak 20 Bantuan untuk setiap peserta yang berada pada rangking 1 sampai dengan 20. Berikut adalah nama-nama yang mendapatkan bantuan sebanyak 20 kepala keluarga yang dapat dilihat pada Tabel 10.

Tabel 10 Nama-nama Penerima bantuan

\begin{tabular}{|c|l|l|l|c|}
\hline No & \multicolumn{1}{|c|}{ Nama } & Net Flow & \multicolumn{1}{|c|}{ Dusun } & Rangking \\
\hline 1 & Iin Saputra & 0,219221 & Dusun Sawang Rt:13/ Rw: 03 No: 09 & 1 \\
\hline 2 & Rabuli Mordip & 0,207286 & Dusun Pelok Rt: 24/ Rw: 08 No: 06 & 2 \\
\hline 3 & Halida & 0,205402 & Dusun Sawang Rt: 14/ Rw: 04 No: 38 & 3 \\
\hline 4 & Sarima & 0,190012 & Dusun Sawang Rt: 14/ Rw: 04 No: 15 & 4 \\
\hline 5 & Jefri & 0,186872 & Dusun Pelok Rt: 24/ Rw: 08 No: 18 & 5 \\
\hline 6 & Jusman & 0,183731 & Dusun Pelok Rt: 24/ Rw: 08 No: 01 & 6 \\
\hline 7 & Tabi'in Samsudi & 0,183731 & Dusun Pelok Rt: 24/ Rw: 08 No: 10 & 7 \\
\hline 8 & Kardi Bujang & 0,182161 & Dusun Sawang Rt:13/ Rw: 03 No: 24 & 8 \\
\hline 9 & Nurdin & 0,182161 & Dusun Pelok Rt:24/ Rw: 08 No: 34 & 9 \\
\hline 10 & Saripah Sahi & 0,181847 & Dusun Pelok Rt: 24/ Rw: 08 No: 32 & 10 \\
\hline 11 & Arpian & 0,179648 & Dusun Sawang Rt: 13/ Rw: 03 No: 20 & 11 \\
\hline 12 & Suparman & 0,174937 & Dusun Pemidingan Rt: 19/ Rw: 06 No: 08 & 12 \\
\hline 13 & Pawadi & 0,172111 & Dusun Pelok Rt: 24/ Rw: 08 No: 14 & 13 \\
\hline 14 & Bujang Dare Yusuf & 0,172111 & Dusun Pemidingan Rt: 18/ Rw: 05 No: 01 & 14 \\
\hline 15 & Sopian Muhammad & 0,16206 & Dusun Pelok Rt: 24/ Rw: 08 No: 19 & 15 \\
\hline 16 & Ramli Bujang Sari & 0,16206 & Dusun Pelok Rt: 23/ Rw: 08 No: 01 & 16 \\
\hline 17 & Abdul Hamid Mathan & 0,16206 & Dusun Pelok Rt: 23/ Rw: 08 No: 06 & 17 \\
\hline 18 & Supardi & 0,157663 & Dusun Sajat Rt: 08/ Rw: 02 No: 33 & 18 \\
\hline 19 & Irpan & 0,156721 & Dusun Pemidingan Rt: 17/ Rw: 05 No: 16 & 19 \\
\hline 20 & Bayati Aliaspar & 0,15201 & Dusun Sawang Rt: 15/ Rw: 04 No: 01 & 20 \\
\hline
\end{tabular}

\section{KESIMPULAN DAN SARAN}

\subsection{Kesimpulan}

Berdasarkan pengujian yang telah dilakukan pada sistem ini dapat diambil kesimpulan sebagai berikut:
Berdasarkan pengujian yang telah dilakukan pada sistem ini dapat diambil kesimpulan sebagai berikut:

1. Rata-rata nilai Net Flow tingkat kemiskinan pada Desa Tengguli adalah 
sebesar -0,000764. Dengan nilai Net Flow terbesar adalah 0,219221 dan nilai Net Flow terkecil adalah -0,362437.

2. Total bantuan yang diberikan oleh pemerintah adalah sebanyak 20 bantuan, yaitu peserta yang berada pada rangking 1 dengan nilai Net Flow 0,219221 sampai dengan rangking 20 dengan nilai Net Flow 0,15201.

3. Jumlah kepala keluarga yang mendapatkan bantuan PKH pada Dusun Pelok adalah 11 kepala keluarga, di Dusun Pemidingan 3 kepala keluarga, di Dusun Sawang 5 kepala keluarga, dan di Dusun Sajat 1 kepala keluarga.

\subsection{Saran}

Terdapat beberapa saran untuk penelitian ini sebagai berikut:

1. Penentuan kriteria yang digunakan lebih dinamis, artinya dapat disesuaikan dengan kebutuhan di Desa yang menggunakan sistem ini.

2. Masukan data administrasi peserta dapat dilengkapi dengan berkas-berkas yang menunjukkan bahwa data yang digunakan adalah benar seperti surat keterangan penghasilan, foto rumah, foto keluarga, kartu keluarga.

\section{DAFTAR PUSTAKA}

[1] pkh.kemsos.go.id, "Apa Itu Program Keluarga Harapan," 1 November 2019. [Online]. Available: //pkh.kemsos.go.id/?pg=tentangpkh-1.

[2] F. H. Banjadoh dan R. Hidayati, Sistem Pendukung Keputusan Untuk Menentukan Siswa Lulusan Terbaik Menggunakan Promethee (Studi Kasus: SMA Negeri 3 Pontianak), Pontianak: Universitas Tanjungpura, 2018.

[3] N. Azizah dan S. Winarti, "Sistem Pendukung Keputusan Seleksi Calon Karyawan Dengan Metode Promethee Studi Kasus Pamella Group Yogyakarta," Jurnal Sarjana Teknik Informatika, pp. 1061-1075, 2014.
[4] Safrizal dan L. Tanti, "Penerapan Metode Promethee Dalam Penyeleksian Siswa Baru (Airlines Staff) pada LPP Penerbangan," Stimik Stikom, pp. 869875, 2015.

[5] B. Yuwono, "Sistem Pendukung Keputusan Menggunakan Metode Promethee (Studi Kasus: Stasiun Pengisian Bahan Bakar Umum)," Telematika, pp. 63-74, 2011.

[6] Diana, Metode Dan Aplikasi Sistem Pendukung Keputusan, Yogyakarta: Deepublish Publisher, 2018.

[7] Ubaidi, "Sistem Pendukung Keputusan Penerimaan Siswa Baru Dengan Metode Promethee (Studi Kasus: Sd Plus Nurul Hikmah Pamekasan)," IDeaTech, pp. 392-399, 2015. 